\title{
PSATHYRELLA CANDOLLEANA (FR.:FR.) MAIRE VAR. CANDOLLEANA (FR.) MAIRE: A NEW RECORD OF MUSHROOM FOR NEPAL
}

\author{
M. K. Adhikari \\ Kathmandu, Nepal.
}

\begin{abstract}
Recently Psathyrella candolleana (Fr.:Fr.) Maire var. candolleana (Fr.) Maire (1913) was gathered from Lainchour, Kathmandu. It is considered as new record for Nepal. The brief description, distribution and the photograph of the species has been included in this paper.
\end{abstract}

Keywords : Psathyrella; Nepal.

\section{INTRODUCTION}

The macro or higher fungi or mushrooms are studied since the contribution of Llyod (1808) and Berkely (1838). The reports on the Nepalese mushroom species can be seen in Adhikari (1995, 1995-96, 1996 2000, 2001, 2009ab, 2011, 2012), Adhikari \& Shrestha (2011) and Adhikari \& Watanabe (2009). Previous reports include Psathyrella lacrymabunda (Bull.: Fr.) Moser $[=$ P. velutina (Pers.: Fr.) Singer $]$ from Chandragiri (Adhikari, 1988a) and P. piluliformis (Bull. : Fr.) Orton from Kakani (Adhikari, 1988b) and Psathyrella sp. from Kathmandu (Bhatt, 1966) and Daman (Pandey, 1976; Cotter, 1987). Psathyrella candolleana was reported by Aryal, Budathoki \& Adhikari (2012) from West Nepal but no photograph and detailed study were provided. This is the first report and description of the taxon from Central Nepal.

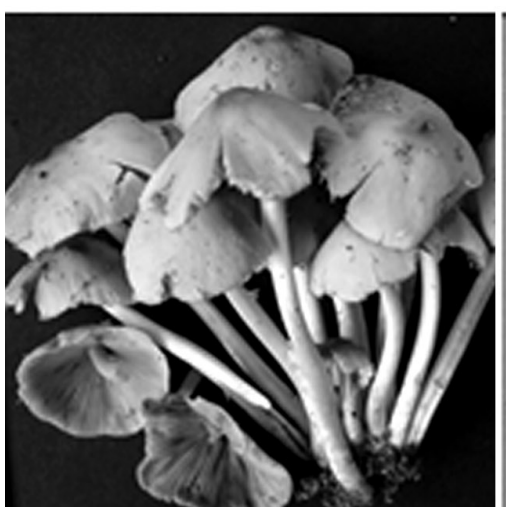

Figure : from left to right - A. Fruit body

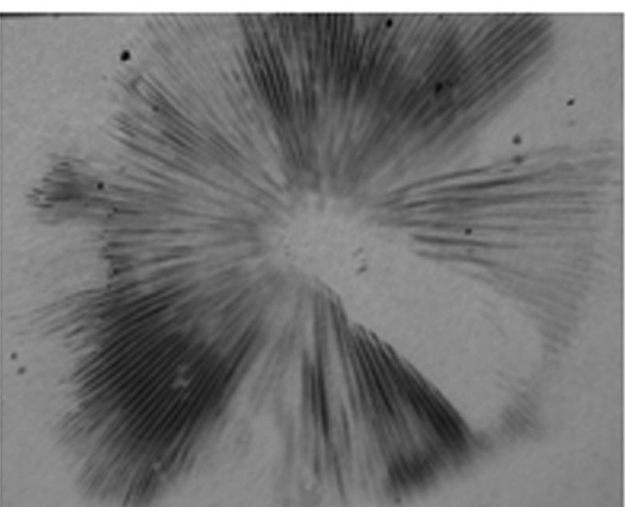

B. Spore print

\section{Enumeration of species}

Psathyrella candolleana (Fr.:Fr.) Maire, var. candolleana (Fr.) Maire (1913). Psathyrella candolleana (Fr.:Fr.) Maire, in Courtecuisse \& Duhem (1994); Guide des champignons de France et d'Europe.268; Courtecuisse (2000), Photo guide des champignons d'Europe, 472; Vigot, (2004), Champignons, 364; Eyssortier et Roux (2011), Les guide des champignon France et Europe, 906; Imazeki, Otani \& Hongo (1988). Fungi of Japan.210.

[Synonyms - Agaricus appendiculatus Bull.; ${ }_{\text {mor }}$ Agaricus appendiculatus var. lanatus Berk. \& Broome; Agaricus candolleanus Fr.; Agaricus candolleanus var. candolleanus Fr.; Agaricus catarius Fr.; Agaricus egenulus Berk. \& Broome; Agaricus stipatus var. appendiculatus (Bull.) Pers.; Drosophila appendiculata

\section{MATERIALS AND METHODS}

In course of investigation of fungi in Kathmandu valley, an Agaricoid fungus was gathered growing in cluster on unknown decayed stump in agricultural field at Lainchour. The photographs were taken immediately in situ. The specimen was studied under microscope consulting various literature noted below. The gathered specimen has been deposited in National Herbarium and Plant Laboratories (KATH), Godavary, Nepal.

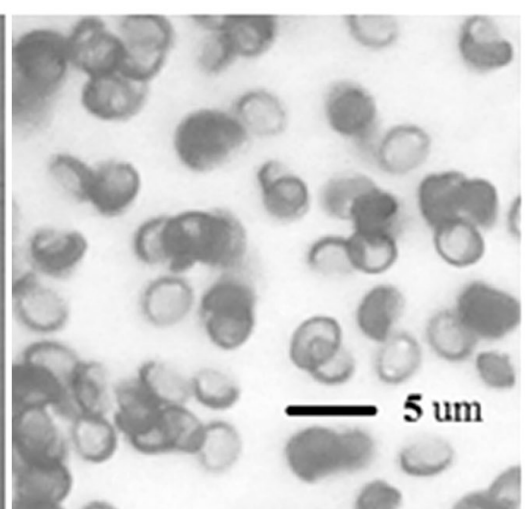

C. Spores
(Bull.) Quél.; Drosophila candolleana (Fr.) Quél.; Hypholoma appendiculatum (Bull.) Quél.; Hypholoma candolleanum (Fr.) Quél.; Hypholoma catarium (Fr.) Massee; Hypholoma egenulum (Berk. \& Broome) Sacc.; Hypholoma felinum Pass.; Hypholoma incertum Peck.; Hypholomopsis appendiculata (Bull.) anon.; Psathyra appendiculata (Bull.) G. Bertrand; Psathyra candolleana (Fr.) Singer; Psathyra corrugis var. vinosa (Corda) Rea; Psathyrella appendiculata (Fr.) Maire; 
Psathyrella appendiculata (Bull.) Maire \& Werner; Psathyrella corrugis var. vinosa (Corda) Berk. \& Broome; Psathyrella egenula (Berk. \& Broome) M.M. Moser; Psathyrella microlepidota P.D. Orton]

Common name - Psathyrella, Psathyrella de De Condolle. Common Psathyrella.

Taxonomic position - Mycota, Basidiomycota, Agaricomycetidae, Agaricales, Coprinaceae.

Description - Pileus 3-10 cm, conico- convex when young, expanding to broadly convex, broadly bellshaped, surface smooth or sometime having fragments of whitish fibrils, often developing shallow radial wrinkles; dry, honey yellow when young, to pale brownish or nearly white as it dries, margin with remnants of hanging partial veil in young ones, mature margin often splitting radially in places. Flesh very thin, brownish to whitish. Stipe 4-10 X 0.3- $0.4 \mathrm{~cm}$, equal, fragile, cylinder, white, hollow, slightly lined, lacking annulus, sometimes with loosely clinging partial veil in a ring-like zone. Lamellae adnate whitish at first, becoming grayish and finally dark brown, crowded. Spore print dark brown to ting of violet brown. Spores $5-6$ X $3.5-5 \mu \mathrm{m}$, oval elliptic, smooth, thick walled.

Odor not distinctive. Edible but not recommended due to uncertainties in identification (Arora, 1986), unknown avoid. (Phillips, 2006)

Specimens examined - growing in cluster in cultivated areas on dead wood stumps, Lainchour, 1380m, 2070/3/9, Kathmandu, no. 207039, Adhikari

Distribution- North America. Europe, Japan, China, Nepal, India

\section{Comments -}

Psathyrella candolleana has saccate to clavate or subcylindric cheilocystidia; pleurocystidia is absent. It is distinguished from Psathyrella piluliformis (Bull.: Fr.) Orton $[=P$. hydrophila (Bull. ex Mérat) Maire $]$ by its smooth surface, dark reddish brown to rusty brown pileus with distinct reminants of veil hanging.

Psathyrella candolleana is known to have subspecies entities evident in literature (Smith, 1972). Psathyrella candolleana var. solitaria A. H. Sm, differs in its solitary habit. P. candolleana var. candolleana (Fr.) Maire appears in groups with campanulate broad pileus, which torn up radially (cheilocystidia utriform) and has slightly smaller spores. Psathyrella candolleana var. indica Push. \& Purush. (2013) is a humus inhabiting fungi with non fragile orange grey pileus, striate margine and subcentral stipe.

\section{REFERENCES}

Adhikari, M. K.1988a. Some higher fungi from Langtang and its adjoining area. Proceedings of the papers National conference on Science \& Technology organized by RONAST, Kathmandu: BSNS 1a : 1, 237241.

Adhikari, M. K.1988b. New records of fleshy fungi from the Kathmandu valley. Cryptogams of the Himalayas.vol.1.The Kathmandu valley. Eds, M. Watanabe and S. B. Malla. National Science Museum, Tsukuba, Japan. 133139.

Adhikari, M. K. 1995. New records of fleshy fungi from the Kathmandu valley. 2 Green World. 6(1): $37-38$
Adhikari, M. K. 1995 - 1996. New records of fleshy fungi from the Kathmandu valley, Nepal. 3 Nat. Hist. Soc. Bull. 5- 6 (1 - 4): 13 - 15

Adhikari, M. K. 1996. Biodiversite des Basidiomycetes au Nepal: etude systematique et biogeographique. Specialite Ecologie-Mycologique.These du Doctorat de L'Universite present devant l'Universite Paul Sabatier, Toulouse, France. No. d'ordre 2309, p. 205.

Adhikari, M. K. 2000. Mushrooms of Nepal. Edited by G. Durrieu, P.U. Printers Battishputali, Kathmandu, Nepal. p. 236

Adhikari, M. K. 2001. New record of fleshy fungi from Kathmandu valley. Nepal - 4. Green World. 7(1): $3-7$

Adhikari, M. K. 2009a. New record of fleshy fungi from Nepal. Bull. Dept. Pl. Res. 31, Department of Plant Resources, Thapathali, Kathmandu, Nepal. p. 1- 10.

Adhikari, M. K. 2009b. Researches on the Nepalese mycoflora: revised account on the history of mycological explorations. Published by K. S. Adhikari, Kathmandu, Nepal, p. 92

Adhikari, M. K. 2011. Some new records and noteworthy higher fungi from Nepal. Bull. Dept. Pl. Res. 33 : 20- 26, Kathmandu, Nepal.

Adhikari, M. K. 2012. Researches on the Nepalese mycoflora-2: checklist of macrofungi (mushrooms). Published by K. S. Adhikari , Kathmandu, Nepal. p. 90.

Adhikari, M. K and Shrestha, K. 2011. New records of some higher fungi (mushrooms) from Nepal. Bull. Dept. Pl. Res. 33 : 12 - 16, Kathmandu, Nepal.

Adhikari, M. K. and Watanabe, K. 2009. Some interesting fungi from Nepal. Bull. Dept. Pl. Res. 31, Department of Plant Resources, Thapathali, Kathmandu, Nepal. p. 16-21.

Aryal, H. P., Budhathoki, U. and Adhikari, M. K. 2012. Mycodiversity in Peepaldanda Community Forest, western tarai region of Nepal.Bull. Dept. Pl. Res. 34 :13 - 17

Berkeley, M. J. 1854a. Decades XLI - XLIII. Indian fungi. Hooker's Jour. Bot. Kew. Gard. Misc. jour. 6 : 129-143. b - Decades XLIV - XLVI. Indian fungi. Ibid. 6: 161-174. c - Decades XLVII - XLVIII. Indian fungi. Ibid. 6: 204-212. d - Decades XLIX - L. Indian fungi. Ibid. 6: 225-235. (reprint 1969, Decades of fungi 1-62, Amsterdam, Asher Co. 280).

Arora, D. 1986. Mushrooms Demystified. Ten Speed Press, Berkely (2 $2^{\text {nd) }}$ Edition.)

Cotter, H. V. T. 1987. The systematics and ecology of boletes with special reference to the genus Suillus and its ectomycorrhizal relationship in Nepal. Dissertation submitted to the faculty of the Virginia Polytechnic Institute and State University in partial fulfillment of the requirement for the degree of Ph. D. in Botany, Blacksburge, Virginia, U. S. A. p. 175.

Lloyd, C. G. 1808. Mycological notes. no. 175.

Pandey, B. D. 1971-1976. Survey, collection, preservation and identification of the mushrooms in Nepal. Nep. Jour. Agri. 6 - 11: 115-129.

Phillips, R. 2006. Mushrooms. Pan MacMillan 20 New Wharf Road, London.

Pushpa, H. and Purushothama, K. B. 2013. Psathyrella candolleana var. indica (Agaricales) a new variety from Karnataka state, India. Int. Jour. Bio. Res. 1(1): 1 - 7.

Singh, S. C. and Nisha. 1976. Some fleshy fungi of Nepal. Jour. Sc. 6 (1): 73-88.

Smith, A. H. 1972. The North American species of Psathyrella. Mem. New York Bot. Gard. 24: 1-633. 